Article

\title{
Effect of Mineral Additives on the Behavior of an Expansive Soil for Use in Highway Subgrade Soils
}

\author{
Yongzhen Cheng ${ }^{1, *}$ and Xiaoming Huang ${ }^{2}$ \\ 1 Faculty of Architecture and Civil Engineering, Huaiyin Institute of Technology, Huai'an 223001, China \\ 2 School of Transportation, Southeast University, Nanjing 210096, China; huangxm@seu.edu.cn \\ * Correspondence: 230139226@seu.edu.cn; Tel.: +86-15251855291
}

Received: 5 December 2018; Accepted: 20 December 2018; Published: 22 December 2018

\begin{abstract}
Black cotton soil (BCS) forms a major soil group in Kenya and is characterized by high shrink/swell potential when exposed to water. A comprehensive series of laboratory tests were performed on BCS treated with lime (0-9\%), volcanic ash (VA, 0-25\%), and their combinations in order to study the physical-mechanical properties and mineralogical changes of the stabilized BCS. Moreover, a test road which replaced the BCS with the lime-VA-stabilized BCS was constructed to investigate the moisture change and soil movement in the BCS foundation. The results revealed that BCS stabilized with combinations of lime and VA shows larger California bearing ratio (CBR) and unconfined compressive strength (UCS) values when compared with a single stabilizer. BCS stabilized with 3\% lime $+15 \%$ VA meets the performance requirements of roadbed materials in accordance with JTG D30-2015. The increase of $\mathrm{pH}$ and electrical conductivity (EC) in the stabilized soil promotes chemical reactions between the stabilizers and BCS to form new cementing agents, which are confirmed by X-ray diffraction (XRD) and transmission electron microscope (TEM) findings. The replacement of BCS with 3\% lime $+15 \%$ VA-stabilized BCS shows an obvious effect on controlling the moisture change and soil movement in the foundation BCS. This research provides a low-cost strategy for making use of the vast resources of BCS in Kenya obtained from foundation excavation.
\end{abstract}

Keywords: black cotton soil; natural pozzolans; physical-mechanical properties; mineralogical change; deformation control

\section{Introduction}

With the fast development of infrastructure construction in Kenya, many highways, municipal roads, and railway lines have been constructed in recent years, such as the Nairobi-Mombasa railway line and Southern Bypass in Nairobi. The construction of the subgrade frequently encounters geotechnical engineering issues caused by black cotton soil (BCS). BCS is a type of clay with high swelling potential when exposed to water [1,2] and is mostly found in the plain region of neighboring Nairobi, in lowlands on the northeastern coast, and in the Victoria lake region of Kenya [3]. The major components in the BCS were found to be clay minerals including montmorillonite, chlorite, vermiculite, and illite, etc. [4]. Such a high content of clay minerals is the main reason for the high expansion of the Nairobi BCS [5]. The water swelling behavior causes serious problems in highway construction if BCSs are directly used for the foundation [6]; otherwise, the BCSs have to be excavated and thrown away. A case in point found in Kenya is that the BCSs were always piled up by the roadside due to the fast development of highway constructions. The increase of the discarded BCS results in serious environmental disaster. To overcome these problems, a facile but low-cost strategy has to be found to make use of such clay in highway construction.

Soil stabilization is the best-known method of making use of clays and can decrease the volume change of such clay due to change in water with the help of stabilizers. Such stabilizers are mixed with 
the soil to reduce the swelling potential and plasticity of expansive clay, improving the durability and strength of the soil [7-13]. The most commonly used stabilizers for soil modification are hydrated lime, ordinary Portland cement, petroleum sulfonate, asphalt, and certain resins [14-18]. Al-Rawas et al. [19] studied soil stabilization using the Atterberg limits, swell percent, and swell pressure tests, and found that lime significantly improved the physical-mechanical properties of expansive soil. $\mathrm{pH}$, electrical conductivity, and X-ray diffraction (XRD) tests were conducted on an expansive soil treated with lime, and Al-Mukhtar [20,21] researched the lime-soil reaction over a short term and the progression of the pozzolanic reaction over a longer term. Industrial byproducts/wastes such as fly ash, cement kiln dust, and rich husk ash can bind soil particles together and reduce water absorption by clay particles due to their pozzolanic properties [22-27]. Atterberg limits, compaction, California bearing ratio (CBR), and unconfined compressive strength (UCS) tests were performed on expansive soil, and Ene and Okagbue [28] found that the optimum physical-mechanical properties of the expansive soil were obtained with the addition of up to $8 \%$ pyroclastic rock dust content. However, the heavy use of these stabilizers will cause a sharp increase in construction cost. A local natural material which is a vast resource and easy for manufacturing needs to be found to decrease the use of conventional stabilizers. Natural volcanic ash (VA), which is composed of mainly rock minerals with minor amounts of volcanic glass fragments, is found abundantly in Kenya.

Its pozzolanic properties make VA able to bind clay particles together and reduce the water swelling of clay. As a result, VA-stabilized soil presents a decrease in the plasticity index and expansive potential and an increase in the strength and durability [29]. Unfortunately, the insufficiency of calcium oxide means that VA cannot obviously improve the strength of clay [30]. The addition of natural pozzolana has a minor effect on the plasticity index of the clays. Natural pozzolana is unsuitable for use alone in soil stabilization. In limited research, VA was used to stabilize clay soil in association with other stabilizers such as ordinary Portland cement and hydrated lime [31]. Clay reacts with VA-lime or VA-cement composite stabilizer, and hydrated calcium silicate or hydrated calcium aluminate is generated to improve the physical-mechanical properties of the clay. The combination of lime and natural pozzolana provides the clay with higher strength than natural pozzolana or lime alone [32]. The use of VA will decrease the cement or lime dosage in the soil stabilization and ultimately results in a low-cost subgrade material.

Unfortunately, research on BCS stabilization with lime and natural pozzolans is quite limited. Although some research was performed to investigate the evolution of mineralogy [33], the use of BCS as a subgrade material has not been yet reported. In this paper, the influence of VA, lime, and their combinations on the physical-mechanical properties of BCS was researched using compaction, Atterberg limits, California bearing ratio (CBR), and unconfined compressive strength (UCS) tests. Meanwhile, the $\mathrm{pH}$, Electrical conductivity (EC), and phase studies such as XRD and transmission electron microscope (TEM) were performed to investigate the change in the chemical and mineralogical characteristics of the stabilized BCS. For evaluating the effect of lime- and VA-stabilized BCS on the controlling the moisture change and soil movement in a BCS foundation, test roads in the Southern Bypass in Nairobi were constructed and observed.

\section{Materials}

\subsection{Black Cotton Soil (BCS)}

BCSs were sampled from the Southern Bypass at Nairobi, Kenya. The basic physical-chemical properties of BCS are presented in Table 1. BCS is characterized by its high plasticity, free swell index, and low strength. The grain size distribution of the BCS samples is presented in Figure 1. The high clay content and cation exchange capacity (CEC) indicate that such soils have high surface activity, which will lead to high potential for moisture absorption. The X-ray diffraction pattern (Ultima IV diffractometer, Rigaku, Japan) measured in accordance with SY/T 5163-2010 [34] is 
presented in Figure 2. The major clay minerals of the BCS are montmorillonite $(\mathrm{M})$ and interstratified illite-montmorillonite (I/M) with small amounts of illite (I) and kaolinite (K).

Table 1. Physical properties and cation exchange capacity (CEC) of BCS.

\begin{tabular}{cc}
\hline Properties (Physical Properties) & Test Values \\
\hline Liquid limit (\%) & 64.3 \\
Plastic limit (\%) & 33.6 \\
Plasticity index (\%) & 30.7 \\
Free swell index (\%) & 165 \\
Optimal moisture content (\%) & 31.5 \\
Maximum dry density (g/cm $\left.{ }^{3}\right)$ & 1.35 \\
California bearing ratio (\%) & 1.6 \\
Unconfined compressive strength (MPa) & 0.215 \\
Cation exchange capacity (meq/100 g) & 58.3 \\
Sodium (Na) (\%) & 2.73 \\
Calcium (Ca) (\%) & 47.1 \\
Magnesium (Mg) (\%) & 4.78 \\
Potassium (K) (\%) & 1.64 \\
\hline
\end{tabular}

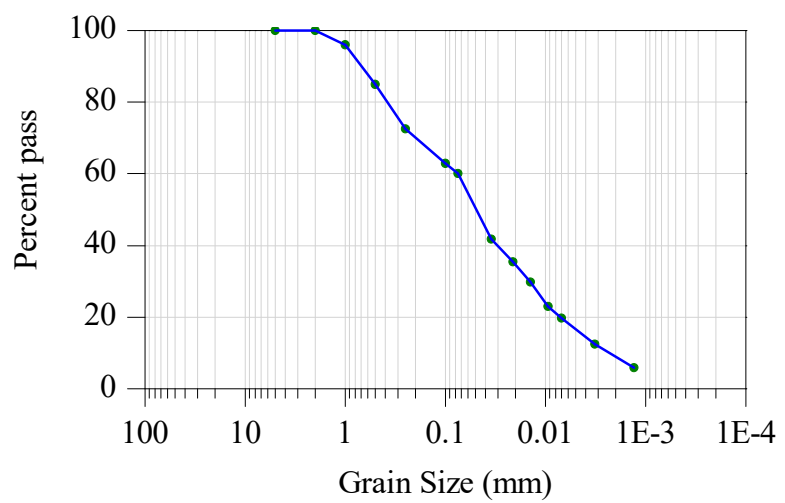

Figure 1. Grain size distribution of the black cotton soil (BCS) samples.

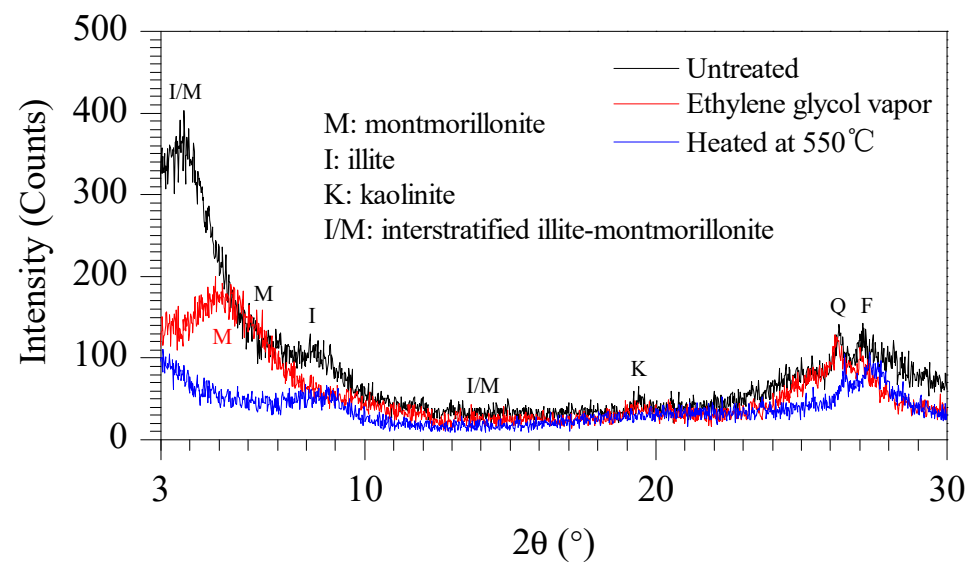

Figure 2. X-ray diffraction of a BCS sample.

\subsection{Natural Pozzolans}

Natural pozzolans were sampled from the Simba quarry near Nairobi. The chemical (oxide) compositions of BCS and VA measured by X-ray Fluorescence (XRF, ADVANT'XP, Thermo, United States) are presented in Table 2. The active components were mainly composed of silica $\left(\mathrm{SiO}_{2}\right)$ and Alumina $\left(\mathrm{Al}_{2} \mathrm{O}_{3}\right)$ in the BCS and VA. Some calcium oxide $(10.69 \%)$ was found in VA, the hydration product of which can react chemically with the active components. 
Table 2. Chemical (oxide) composition of BCS and volcanic ash (VA).

\begin{tabular}{ccccccccccccc}
\hline Oxides (\%) & $\mathbf{C a O}$ & $\mathbf{M g O}$ & $\mathrm{Fe}_{2} \mathbf{O}_{3}$ & $\mathbf{A l}_{2} \mathbf{O}_{3}$ & $\mathbf{S i O}_{2}$ & $\mathbf{K}_{\mathbf{2}} \mathbf{O}$ & $\mathbf{N a}_{2} \mathbf{O}$ & $\mathbf{S O}_{3}$ & $\mathbf{P}_{\mathbf{2}} \mathbf{O}_{5}$ & $\mathbf{M n O}$ & $\mathrm{TiO}_{2}$ & $\mathbf{L O I}^{\mathbf{a}}$ \\
\hline $\mathrm{BCS}$ & 1.70 & 0.95 & 9.44 & 16.89 & 50.34 & 1.01 & 0.76 & 0.15 & 0.02 & 0.30 & 0.90 & 17.5 \\
$\mathrm{VA}$ & 10.69 & 11.69 & 12.43 & 13.35 & 43.26 & 1.29 & 2.76 & 0.07 & 0.54 & 0.17 & 2.85 & 0.32 \\
\hline
\end{tabular}

${ }^{\text {a }}$ Loss on ignition.

\subsection{Hydrated Lime}

Hydrated lime was used as another additive to stabilize the BCS. The lime was sampled from a local lime company. The passing rate of the lime through an $80 \mu \mathrm{m}$ sieve was $100 \%$, and its composition was $96.2 \% \mathrm{Ca}(\mathrm{OH})_{2}$ and $3.8 \%$ other oxides.

\section{Experimental Methods and Tests}

\subsection{Physical-Mechanical Properties Measurements}

The physical-mechanical properties of the stabilized BCS include compaction characteristics, Atterberg limits, California bearing ratio (CBR), and unconfined compressive strength (UCS). The laboratory tests were conducted in accordance with JTG E40-2007 and JTG E51-2009 (Chinese standard) [35,36]. BCS particles were firstly ground and passed through sieves with $0.5 \mathrm{~mm}$ and $2 \mathrm{~mm}$ openings to test the physical and mechanical properties, respectively. Meanwhile, the natural pozzolans were ground and passed through a $75 \mu \mathrm{m}$ sieve. Then, the BCS, VA, and lime were mixed and cured according to JTG E40-2007. After 1 day of curing, the Atterberg limits and the standard Proctor test were performed, and the optimal moisture content (OMC) and the maximum dry density (MDD) of the stabilized BCS could be determined. Specimens for testing the CBR were prepared at the OMC under the compaction effort per volume, same as the standard Proctor test. After immersing the specimens in water for 4 days, penetration testing was carried out at a penetration rate of $1.25 \mathrm{~mm} / \mathrm{min}$. The CBR value was determined based on standard pressure and the specific pressure of $2.5 \mathrm{~mm}$ penetration. The UCS test on the stabilized BCS was conducted as per JTG E51-2009. The breakdown pressure was measured at a loading speed of $0.1 \mathrm{~mm} / \mathrm{min}$ to compute the UCS values in the cross-sectional area of the specimen.

\subsection{Measurements of $\mathrm{pH}$ and Electrical Conductivity}

The $\mathrm{pH}$ test was conducted as per JTG E40-2007; during this process, the electrical conductivity (EC) of the slurry was also measured. A quantity of $10 \mathrm{~g}$ of oven-dried stabilized soil constituting particles passing through a $1 \mathrm{~mm}$ sieve was sampled and dispersed in $50 \mathrm{~mL}$ of distilled water. The mixtures were poured into a wide-mouth bottle and oscillated for $3 \mathrm{~min}$. After 1 and $3 \mathrm{~h}$, and 1, 3, 7 , and 28 days of curing, the EC and $\mathrm{pH}$ were measured using $25 \mathrm{~mL}$ of slurry taken from the mixture.

\subsection{Mineralogical Phase Measurements}

Characterizations including X-ray diffraction (XRD, Ultima IV diffractometer, Rigaku, Japan) and electronic microscopy observation were conducted as follows. The oven-dried stabilized BCSs were ground until all particles could pass through a $40 \mu \mathrm{m}$ sieve. Then, the XRD patterns were determined using an Ultima IV diffractometer ( $\mathrm{Cu} \mathrm{K} \alpha$ radiation). Data were recorded in the 2 Theta range of 5-60 with a speed of $0.02^{\circ} / 20 \mathrm{~s}$ per step. For the transmission electron microscope (TEM, JEOL, Japan) characterization, the slurry of stabilized BCS was dropped onto a glass sheet; then, TEM images of the air-dried samples were determined using a JEOL JEM-2100F apparatus.

\subsection{Measurements of Moisture Content and Settlement}

Moisture content and settlement measurements were performed on the test roads. Twelve NHSF48UR moisture sensors with an accuracy of $\pm 2 \%$ were buried in the foundation at regular 
intervals to monitor the moisture fluctuation of the BCS. The settlement plate, which included a baseplate $(500 \times 500 \times 8 \mathrm{~mm})$ and several measuring bars $(40 \mathrm{~mm}$ external diameter, $30 \mathrm{~mm}$ inner diameter), was installed on the surface of the BCS to measure the foundation deformation using a leveling instrument.

\section{Results and Discussion}

\subsection{Physical-Mechanical Properties}

\subsubsection{OMC and MDD}

The OMC and MDD of the stabilized BCS as determined following JTG E51-2009 are presented in Figure 3. It is quite clear to observe that MDD decreased and OMC increased with increasing lime content. The VA-stabilized BCS presents an inverse variation tendency since the unreacted volcanic ash coats BCS to form large aggregates and increase the dry density of the mixes. The results seem to not be in accordance with the conventional conclusion. The conventional view suggests that the pozzolanic reaction of VA with the soil constituents tends to increase the optimum moisture content [26]. In this study, all mixes were tested at a curing time of $24 \mathrm{~h}$. The pozzolanic reaction might only just be starting in such a short time, and a small quantity of reaction products could be generated due to the low content of calcium oxide (10.69\%) in VA. The compaction characteristics of the stabilized soil depend on both specific gravity and the grain size distribution of the soil and VA. The soils will be coated by the VA to form large aggregates, and the unreacted VA tends to increase the dry density of the mixes.

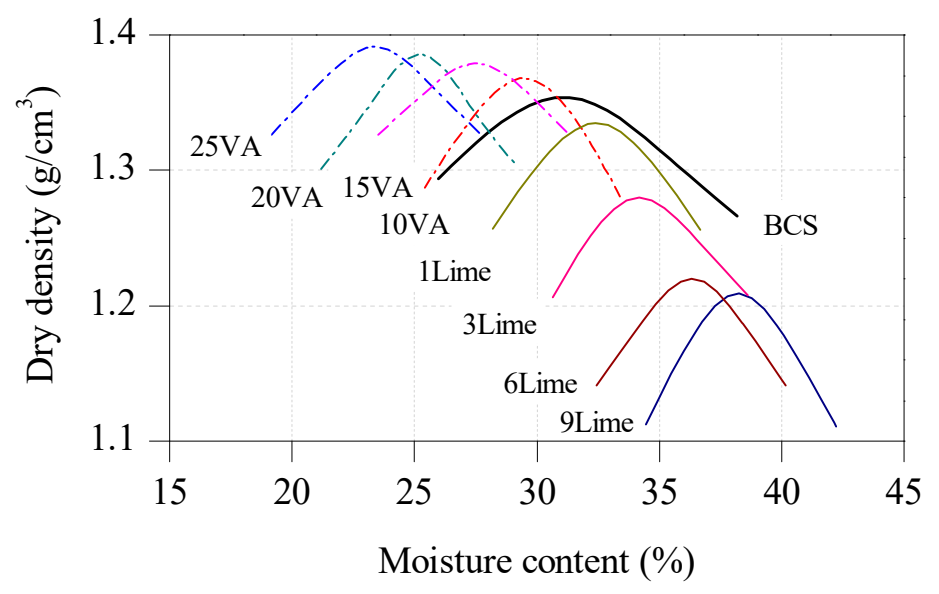

Figure 3. Influence of lime and VA content on the optimal moisture content (OMC) and maximum dry density (MDD) of BCS.

\subsubsection{Determining the Lime and Natural Pozzolans Dosage}

Table 3 presents the liquid limit, plastic limit, and plasticity index of the stabilized BCS. The lime-stabilized BCS presents a marginal decrease in liquid limit, which decreased from $64.3 \%$ to $58.3 \%$ on the addition of $9 \%$ lime. However, the liquid limit of BCS stabilized with VA, and combined additives presented a rapid decrease with increasing additive content. With the addition of $25 \% \mathrm{VA}$ and the combination of 3\% lime $+20 \% \mathrm{VA}$, the liquid limit of the stabilized BCS decreased from $64.3 \%$ to $51.6 \%$ and $46.6 \%$, respectively. Similar behavior was observed by Al-Rawas et al. [19] using lime, cement, and artificial pozzolan as soil additives. However, lime-stabilized BCS presented an obvious decrease in plasticity index due to the increase of the plastic limit. The plasticity index of lime-stabilized BCS decreased from $30.7 \%$ to $8.3 \%$ on the addition of $9 \%$ lime. The plasticity indices of BCS stabilized with $25 \%$ VA and the combination of $3 \%$ lime $+20 \%$ VA were $22.7 \%$ and $22.2 \%$, respectively. 
Table 3. Atterberg limits of unstabilized and stabilized BCS.

\begin{tabular}{cccc}
\hline Samples & Liquid Limit (\%) & Plastic Limit (\%) & Plasticity Index (\%) \\
\hline Untreated soil & 64.3 & 33.6 & 30.7 \\
1\% lime & 65.6 & 35.7 & 29.9 \\
3\% lime & 68.1 & 41.9 & 26.2 \\
6\% lime & 63.4 & 45.8 & 17.6 \\
$9 \%$ lime & 58.3 & 50.0 & 8.3 \\
10\% VA & 58.2 & 30.6 & 27.6 \\
15\% VA & 56.5 & 31.5 & 25.0 \\
20\% VA & 55.1 & 30.3 & 24.8 \\
25\% VA & 51.6 & 28.9 & 22.7 \\
$1 \%$ lime + 15\% VA & 58.4 & 30.5 & 27.9 \\
$1 \%$ lime + 20\% VA & 59.4 & 32.2 & 27.2 \\
$3 \%$ lime + 15\% VA & 49.2 & 25.4 & 23.8 \\
$3 \%$ lime + 20\% VA & 46.6 & 24.4 & 22.2 \\
\hline
\end{tabular}

The variation of the California bearing ratio (CBR) with dosages of stabilizers is presented in Figure 4. The lime increases the CBR of the BCS from $4.7 \%$ to $25.2 \%$ and decreases the expansion ratio of the BCS from $3.1 \%$ to $0.3 \%$ with the addition of lime from $1 \%$ to $9 \%$. The BCS stabilized with VA presents a poor result compared with the lime. VA increases the CBR of BCS from $2.2 \%$ to $4.5 \%$ and decreases the expansion ratio of BCS from $2.6 \%$ to $2.1 \%$ with the addition of VA from $10 \%$ to $25 \%$. The CBR of BCS presents a rapid increase with the use of the composite stabilizer. The CBR of BCS stabilized by composite stabilizer is $24.7 \%$ with the addition of $3 \%$ lime $+15 \% \mathrm{VA}$, and the stabilization effect is similar to that of $9 \%$ lime.

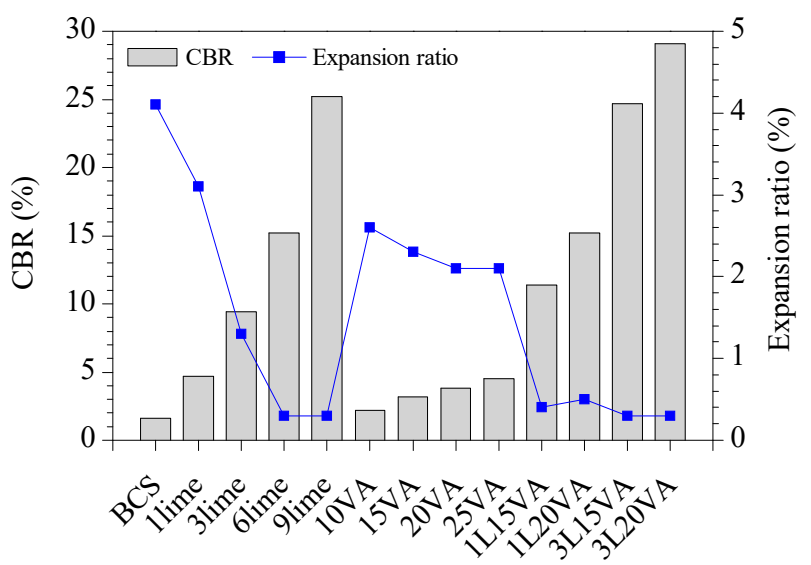

Figure 4. Influence of stabilizer content on the California bearing ratio (CBR) and expansion ratio of BCS.

According to JTG D30-2015 (Chinese standard) [37], the liquid limit and the plasticity index of subgrade soils must be less than $50 \%$ and $26 \%$, respectively. The CBR of the clay must meet the requirements presented in Table 4. The VA-stabilized BCS can only be used as roadbed materials for a low-volume road. The lime-stabilized BCS, as a roadbed material, can pave a high-grade road, and BCS stabilized with only 3\% lime can meet the highest CBR requirement. For this target, the least amount of composite stabilizer required is $1 \%$ lime $+15 \%$ VA. Considering the requirement of the Atterberg limits, BCS stabilized with $3 \%$ lime $+15 \%$ VA is well suited as a roadbed material.

Table 4. Minimum CBR of roadbed materials [37].

\begin{tabular}{ccccc}
\hline Traffic Classification & $\begin{array}{c}\text { Depth Under } \\
\text { Pavement (M) }\end{array}$ & $\begin{array}{c}\text { Expressway/First-Class } \\
\text { Highway }\end{array}$ & $\begin{array}{c}\text { Second-Class } \\
\text { Highway }\end{array}$ & $\begin{array}{c}\text { Third-/Fourth-Class } \\
\text { Highway }\end{array}$ \\
\hline Any Level ofTraffic & $0.0-0.3$ & $8 \%$ & $6 \%$ & $5 \%$ \\
Light/Medium Traffic & $0.3-0.8$ & $5 \%$ & $4 \%$ & $3 \%$ \\
Heavy/Very Heavy Traffic & $0.3-1.2$ & $5 \%$ & $4 \%$ & - \\
\hline
\end{tabular}




\subsubsection{Unconfined Compressive Strength (UCS)}

The increase in the UCS of the stabilized BCS following the increase of stabilizer dosage and curing time is shown in Figure 5. Lime-stabilized BCS presents a prominent increase in UCS. Lime increases the UCS of BCS from 0.215 MPa to 2.2 MPa and 3.5 MPa with the additions of $6 \%$ and $9 \%$, respectively. This behavior is attributed to the reactions between the soil and lime, including cation exchange, flocculation, carbonation, and pozzolanic reaction. The use of VA shows poor results when compared with lime. Even when $25 \%$ VA was added, the UCS of VA-stabilized BCS only increased from $0.215 \mathrm{MPa}$ to $0.81 \mathrm{MPa}$ after 28 days of curing. Low $\mathrm{pH}$ can be observed in the VA-stabilized clay [38], the few hydroxyl ions $\left(\mathrm{OH}^{-}\right)$provided by VA-soil mixes lead to slow progress of the pozzolanic reaction, and a low UCS was observed in VA-stabilized BCS.

The combinations of lime and VA for stabilizing BCS present a better result than do the single stabilizers. The UCS of BCS stabilized with a combination of 3\% lime and 15\% VA reaches $1.95 \mathrm{MPa}$ after 28 days of curing and is higher than the UCS of BCS stabilized with $3 \%$ lime or 15\% VA, for which the UCS values are $1.5 \mathrm{MPa}$ and $0.56 \mathrm{MPa}$, respectively. The reason for this might be that the calcium hydroxide in lime accelerated the pozzolanic reaction between the clay soil and VA. A similar trend was observed by Harichane et al. [39] in stabilizing the clay obtained from a site situated near the town of Chlef in west Algeria. The UCS of clays stabilized with the combination of $4 \%$ lime $+20 \%$ pozzolana was $1.66 \mathrm{MPa}$ after 28 days of curing, which is about 16 and 1.6 times those of clays stabilized with $20 \%$ pozzolana and $4 \%$ lime, respectively. Natural pozzolana cannot be employed solely for soil stabilization. However, lime-stabilized soils can be intensified by adding between $10 \%$ and $20 \%$ natural pozzolana.
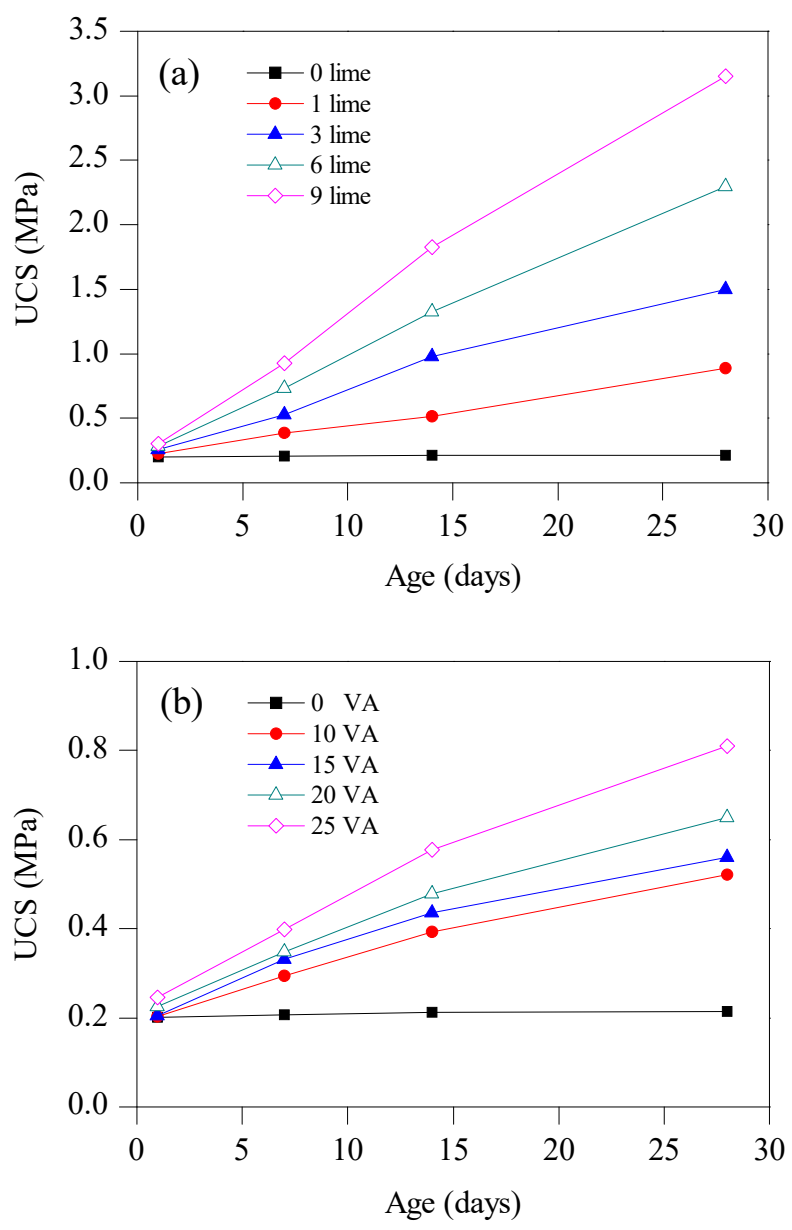

Figure 5. Cont. 


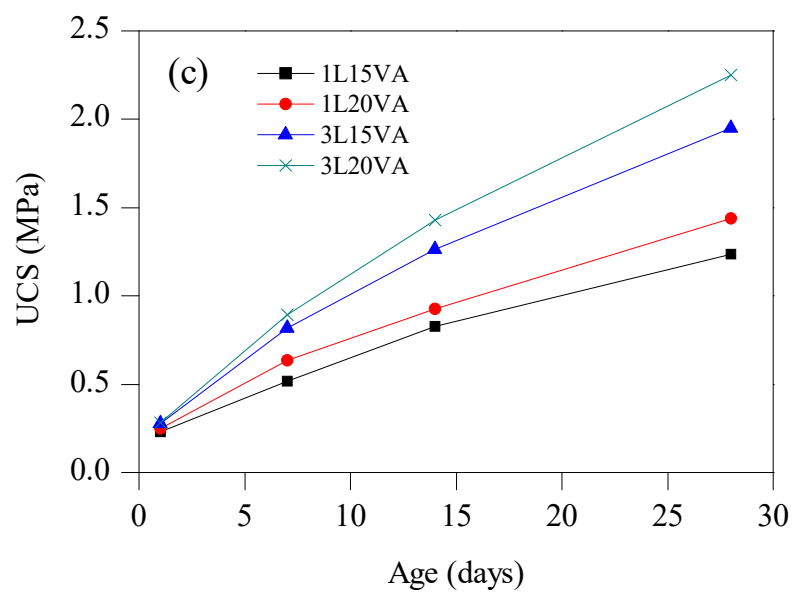

Figure 5. Influence of (a) lime, (b) VA, and (c) mixed stabilizer content on the UCS of BCS.

\subsection{Mineralogical Changes of Stabilized BCS}

\subsubsection{Evolution of $\mathrm{pH}$ and $\mathrm{EC}$}

The variation of $\mathrm{pH}$ with stabilizer dosage and curing time is shown in Figure 6. The increase in the $\mathrm{pH}$ of the stabilized BCS indicates that the solubility of aluminate and silicate in soil increases, which can accelerate the pozzolanic reaction between the soil and stabilizers. The $\mathrm{pH}$ decreases with increasing curing time due to the consumption of stabilizers.

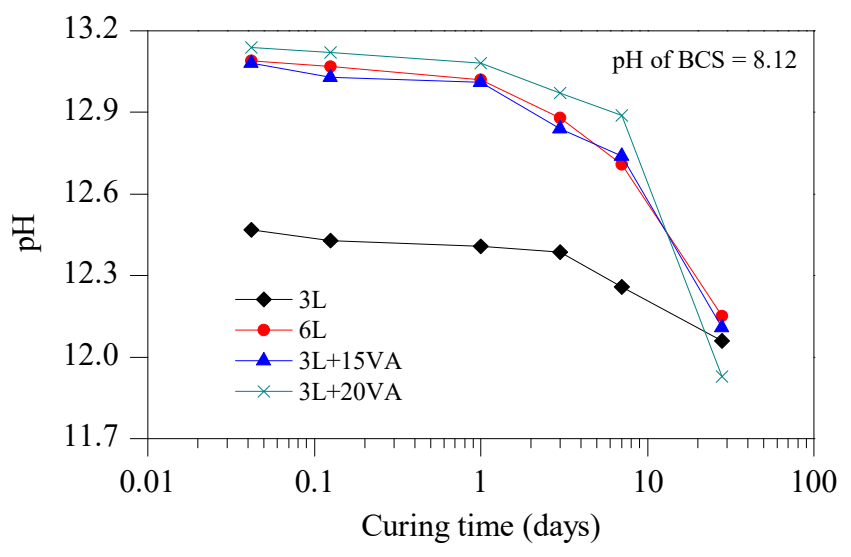

Figure 6. Variation of $\mathrm{pH}$ in stabilized BCS with curing time.

The variation of electrical conductivity (EC) with stabilizer dosage and curing time is shown in Figure 7. The increase in EC of the stabilized BCS indicates the increase of exchangeable cations in the stabilizers-soil mixtures due to the dissolution of VA and lime in the stabilized soil, which can accelerate cation exchange between the calcium cation of the stabilizers and the cations absorbed on the surfaces of BCS particles. The effect of this process results in the closeness of soil particles and the improvement of the physical-mechanical properties of the BCS. The EC of stabilized BCS suffers a sharp reduction during the initial stage due to cation exchange, followed by a slow decrease due to the consumption of cations and hydroxide ions for the pozzolanic reaction. 


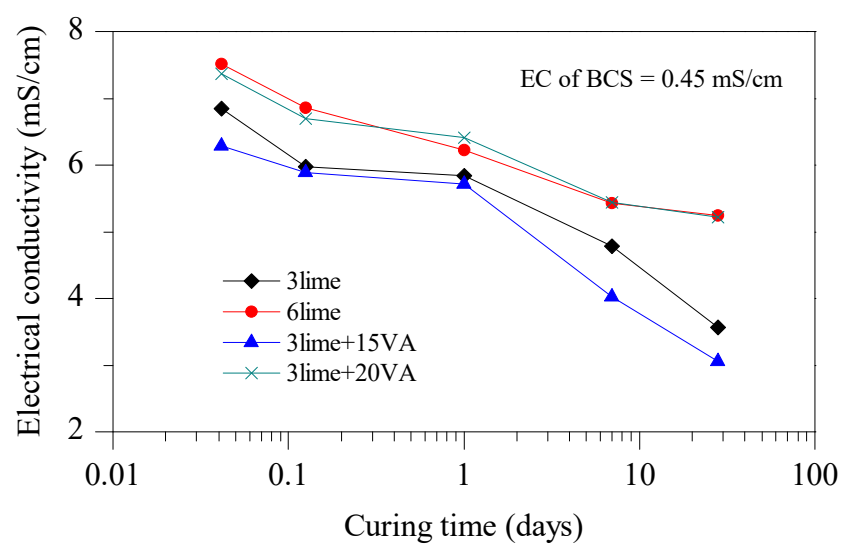

Figure 7. Variation of electrical conductivity (EC) in stabilized BCS with curing time.

\subsubsection{Mineralogical Phase Analysis}

The X-ray diffraction pattern of the stabilized BCS is presented in Figure 8. The similarity of the diffractogram of $15 \%$ VA-stabilized BCS to that of natural BCS illustrates that only a small amount of VA reacts with BCS. In this instance, only a few new minerals such as augite and wollastonite are found in the mixture. The new diffraction peaks in 3\% lime + 15\% VA-stabilized BCS, which are found at 2 theta angles of $18.20^{\circ}, 34.25^{\circ}, 47.20^{\circ}, 50.95^{\circ}$, and $54.45^{\circ}$, are ascribed to $\mathrm{Ca}(\mathrm{OH})_{2}$. After 28 days, the disappearance of these diffraction peaks indicates the consumption of $\mathrm{Ca}(\mathrm{OH})_{2}$. Moreover, a new mineral, calcium aluminate hydrate, is found at a 2 theta angle of $19.85^{\circ}$.

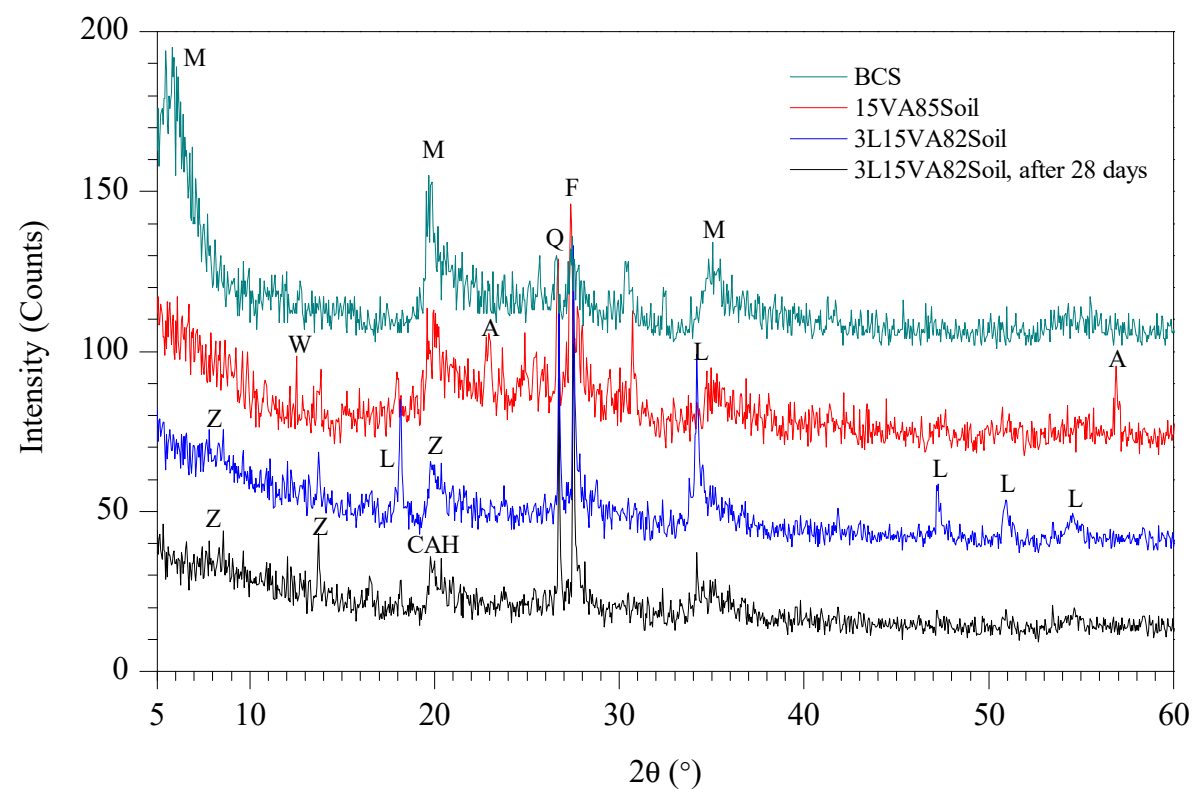

Figure 8. X-ray diffraction of unstabilized and stabilized BCS. (Annotations show $\mathrm{M}=$ montmorillonite, $\mathrm{Q}=$ quartz, $\mathrm{F}=$ feldspar, $\mathrm{A}=$ augite, $\mathrm{Z}=$ zeolite, $\mathrm{W}=$ wollastonite, $\mathrm{L}=$ lime, and $\mathrm{CAH}=$ calcium aluminate hydrate).

Figure 9 presents the TEM images of natural BCS, stabilized BCS with 15\% VA, and stabilized BCS with 3\% lime $+15 \%$ VA. Multilayer sheet structures, which are the typical morphology of clay minerals, are observed in the natural BCS [40]. This illustrates that clay minerals are the major components in BCS, which is consistent with the XRD results. The block-shaped particles found in the VA-stabilized BCS are ascribed to VA. The coexistence of BCS and VA can explain the poor effect of VA on the physical-mechanical properties of the BCS. After 28 days of curing, sheet structures can still be found in the $3 \%$ lime $+15 \%$ VA-stabilized BCS. However, the corrosion of such sheet structures and the 
appearance of the new small particles illustrates the decrease of the clay minerals and the formation of new minerals.
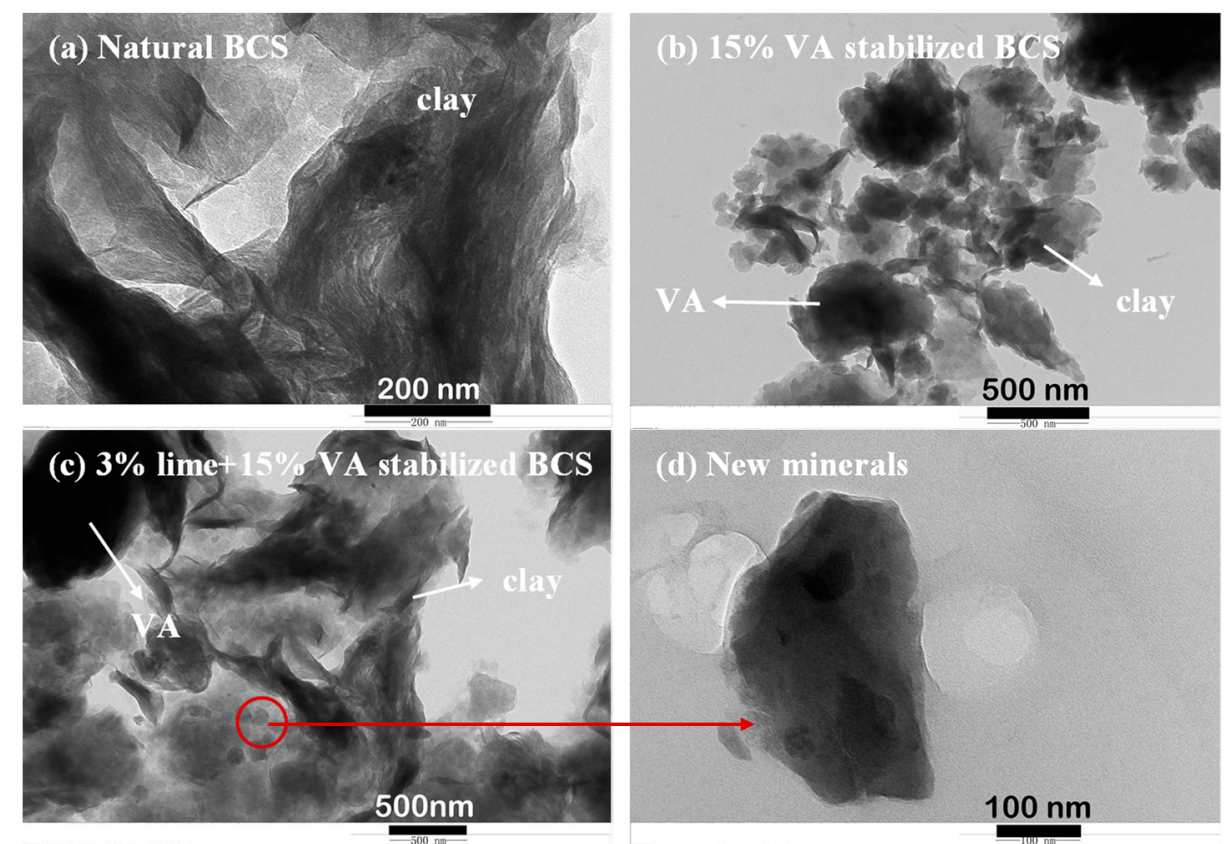

Figure 9. TEM images of stabilized soil samples.

\subsection{Field Tests and Observations}

The effectiveness of replacing BCS with BCS stabilized with lime and natural pozzolans to control the heave of a highway embankment was investigated. The test road was constructed at the Southern Bypass of Nairobi where the soil profile is about $3 \mathrm{~m}$ thick black cotton soil followed by gravel soil. Figure 10 shows the construction of the highway subgrade. The excavation depth of the BCS foundation was $0.8 \mathrm{~m}$; after embedding a moisture content sensor in the BCS, the $3 \%$ lime $+15 \%$ VA-stabilized BCS was backfilled into the foundation ditch. In contrast, a test road was constructed replacing the gravel soil with BCS. Before the construction of the highway embankment, settlement plates located at the edge and center of the pavement were installed.

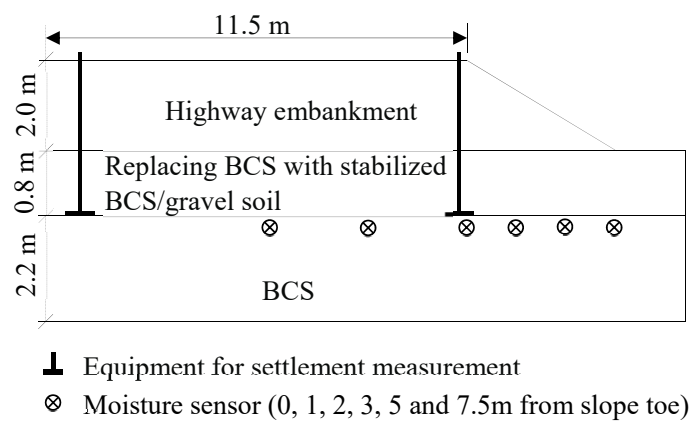

Figure 10. Schematic diagram of the field test replacing BCS with $3 \%$ lime $+15 \%$ VA-stabilized BCS/gravel soil.

The moisture migration and soil movement of the foundation BCS were measured in a dry-wet cycle from 13 July 2016 to 20 November 2016. Figure 11 presents the moisture change of the foundation BCS below the treated soil cushion. There was a small change in moisture content of the BCS at the different monitoring points. When the BCS was replaced with soil stabilized with lime and natural pozzolans, the maximum decrease of moisture content located at the slope toe was $2.8 \%$, and the 
maximum increase of moisture content located $7.5 \mathrm{~m}$ away from the slope toe was $2.67 \%$. When the BCS was replaced with gravel soil, the maximum variation of moisture content located at the slope toe was $4.44 \%$. The moisture change in that BCS has no evident regularity and appears to be little affected by soil surface evaporation and rainfall infiltration. Therefore, moisture migration in the soil is ascribed to the uneven distribution of initial matric suction in the foundation BCS.
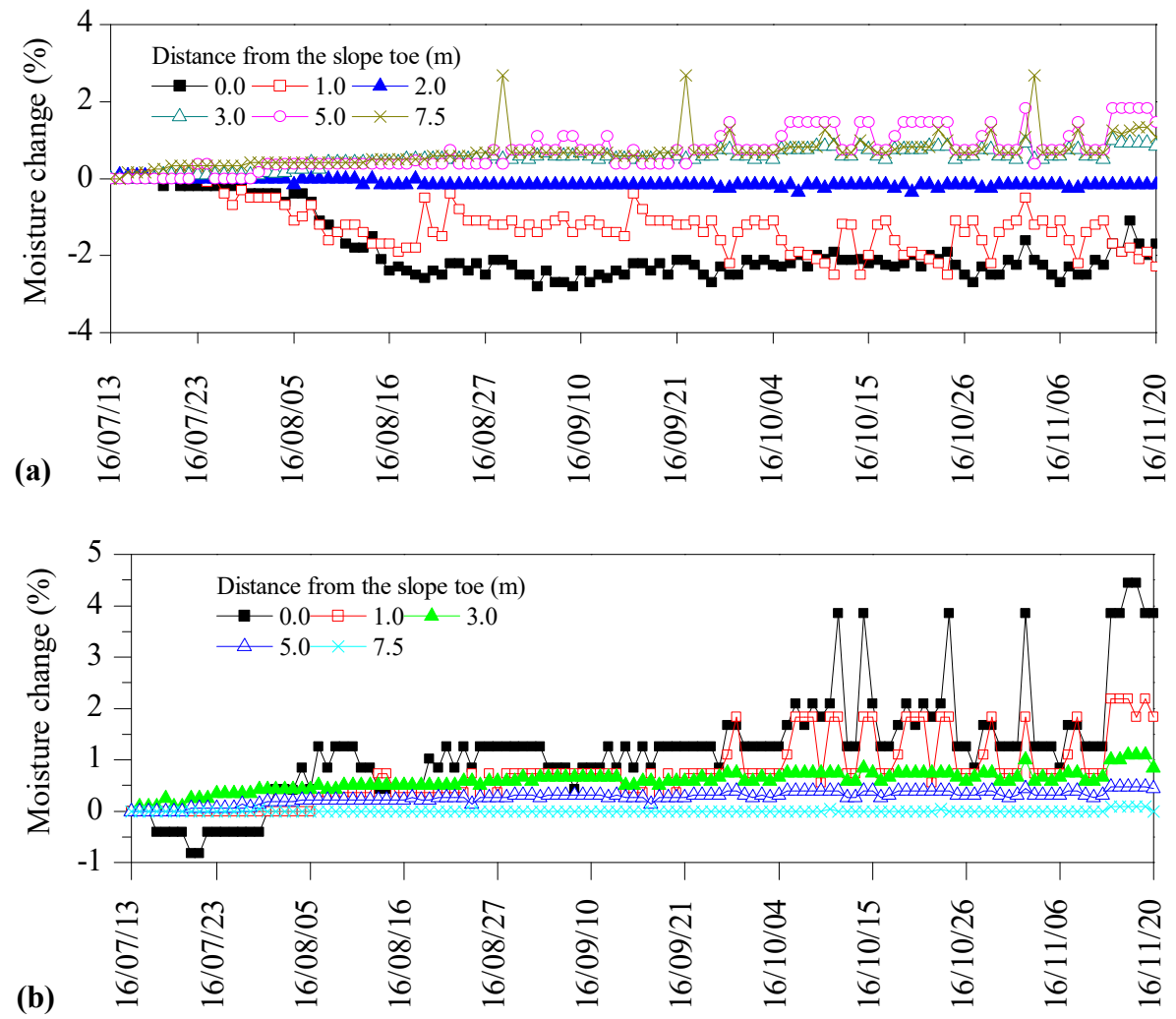

Figure 11. Moisture change in foundation BCS with time during the period July 2016-November 2016. Replacement of BCS with (a) soil stabilized with lime and natural pozzolans and (b) gravel soil.

The vertical displacement of the BCS foundation from July 13, 2016 to November 20, 2016 is presented in Figure 12. The settlement and heave of the BCS foundation appear alternately during the following dry season and rainy season, and the settlement shows an increasing trend. The small vertical deformation of the BCS foundation was measured on the edge of the pavement and in the center of the road. The maximum and minimum vertical deformations of the BCS foundation replacing BCS with soil stabilized with lime and natural pozzolans, both measured on the edge of the pavement, were $4 \mathrm{~mm}$ and $10 \mathrm{~mm}$, respectively. The difference in vertical deformation of the BCS foundation increased with increasing observation time. However, the measured vertical deformation differential was not large, and the maximum value was only $12 \mathrm{~mm}$. When BCS was replaced with gravel soil, a smaller vertical deformation differential of only $5 \mathrm{~mm}$ was measured in the BCS foundation. Small vertical deformation differentials were measured on the two test roads; one interpretation for this is that the test roads were not constructed on the main line. The vertical deformation in the embankment was not affected by traffic loading. Only rainfall and surface evaporation affected the test roads. Either soil stabilized by lime and natural pozzolans or gravel soil can prevent rainfall from infiltrating into BCS layers. Meanwhile, there was a small difference when replacing BCS with soil stabilized with lime and natural pozzolans or gravel soil. Hence, soil stabilized with lime and natural pozzolans could become one option for treating BCS. 

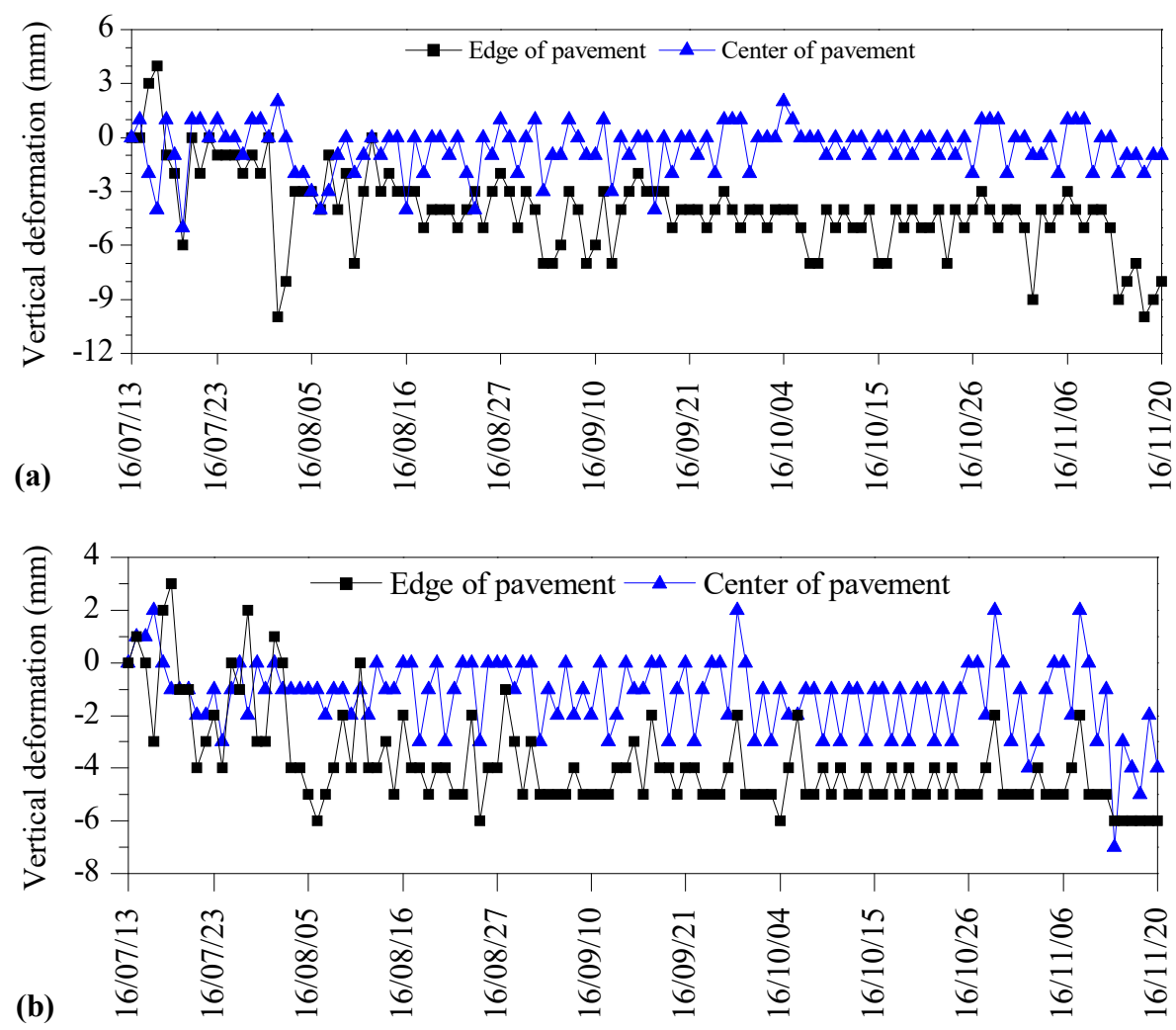

Figure 12. Vertical displacement of the BCS foundation during the period July 2016-November 2016. Replacement of BCS with (a) soil stabilized with lime and natural pozzolans and (b) gravel soil.

\section{Conclusions}

In this research, the physical-mechanical properties of BCS stabilized with lime, VA, and their combination were investigated using compaction, Atterberg limits, CBR, and UCS tests. $\mathrm{pH}, \mathrm{EC}, \mathrm{XRD}$, and TEM tests were conducted to observe the change in mineral phases. Test roads were constructed replacing BCS with the stabilized soil and gravel soil to investigate the moisture change and soil movement in the BCS foundation. The following conclusions are drawn:

1. BCS is characterized as having high clay mineral content, plasticity index, and swelling potential, which indicate that BCS is a typical expansive soil.

2. Lime can vastly improve the physical-mechanical properties of BCS. VA can also decrease the liquid limit and plasticity index of BCS and increase the CBR and UCS of BCS, but has no significant effect. BCS stabilized with combinations of lime and VA presents a better effect than a single stabilizer.

3. According to JTG D30-2015, BCS stabilized with 3\% lime + 15\% VA meets the performance requirements of roadbed materials and could become one option for treating BCS in Kenya.

4. The consumption of stabilizers indicates that BCS reacts with stabilizers to form new minerals, as observed by XRD and TEM.

5. BCS stabilized with $3 \%$ lime $+15 \%$ VA shows a better effect in controlling both the moisture change and soil movement of the foundation BCS.

Author Contributions: Y.C. and X.H. proposed the research method of analyzing the effect of lime and natural pozzolans on BCS stabilization. The experiments were performed and the manuscript was written by Y.C.

Funding: This research was funded by the project of China Communication and Construction Co. entitled "To Develop Sets of Techniques for Highway Construction in Black Cotton Soil Regions, East African", grant number 2013-ZJKJ-02. 
Acknowledgments: The authors thank the engineering technicians of China Road and Bridge Corporation (Kenya) for their assistance in the collection of materials for this research and the anonymous reviewers for their careful review and critique, which led to the improvement of the article.

Conflicts of Interest: The authors declare that there are no conflicts of interest regarding the publication of this paper.

\section{References}

1. Kanyanjua, S.M.; Keter, J.K.; Okalebo, R.J.; Verchot, L. Identifying potassium-deficient soils in Kenya by mapping and analysis of selected sites. Soil Sci. 2006, 171, 610-626. [CrossRef]

2. Sharma, A.K.; Sivapullaiah, P. Ground granulated blast furnace slag amended fly ash as an expansive soil stabilizer. Soils Found 2016, 56, 205-212. [CrossRef]

3. Ackroyd, L.W.; Husain, R. Residual and lacustrine black cotton soils of northeast Nigeria. Geotechnique 1986, 36, 13-18. [CrossRef]

4. Zhang, P.P.; Huang, J.Q.; Shen, Z.P.; Wang, X.L.; Luo, F.; Zhang, P.; Wang, J.; Miao, S.D. Fired hollow clay bricks manufactured from black cotton soils and natural pozzolans in Kenya. Constr. Build. Mater. 2017, 141, 435-441. [CrossRef]

5. $\quad$ Miao, S.D.; Shi, J.Z.; Sun, Y.B.; Zhang, P.; Shen, Z.P.; Nian, H.G.; Huang, J.Q.; Wang, X.Q.; Zhang, P.P. Mineral abundances quantification to reveal the swelling property of the black cotton soil in Kenya. Appl. Clay Sci. 2018. [CrossRef]

6. Wang, X.F.; Wang, Y.; Zhang, Y.H. Design for Treatment of Subgrade on Black Cotton Soil (BCS). Highway 2012, 9, 46-53. (In Chinese)

7. Croft, J.B. The processes involved in the lime-stabilisation of clay soils. In Proceedings of the 2nd Australian Road Research Board (ARRB) Conference, Melbourne, Australian, 31 May-1 June 1964.

8. Ola, S.A. The potentials of lime stabilization of lateritic soils. Eng. Geol. 1977, 11, 305-317. [CrossRef]

9. Anisur Rahman, M.D. The potentials of some stabilizers for the use of lateritic soil in construction. Build. Environ. 1986, 21, 57-61. [CrossRef]

10. George, S.Z.; Ponniah, D.A.; Little, J.A. Effect of temperature on lime-soil stabilization. Constr. Build. Mater. 1992, 6, 247-252. [CrossRef]

11. Wang, Z.F.; Shui, S.L.; Yin, Y.Y.; Xu, Y.S. Rapid field evaluation of the strength of cement-stabilized clayey soil. Bull. Eng. Geol. Environ. 2015, 74, 991-999. [CrossRef]

12. Aldaood, A.; Bouasker, M.; Al-Mukhtar, M. Effect of long-term soaking and leaching on the behaviour of lime-stabilised gypseous soil. Int. J. Pavement Eng. 2015, 16, 11-26. [CrossRef]

13. Escolano, F.; Sánchez, J.R.; Pacheco-Torres, R.; Cerro-Prada, E. Strategies on Reuse of Clayey Expansive Soils as Embankment Material in Urban Development Areas: A Case Study in New Urbanized Zones. Appl. Sci. 2018, 8, 764-776. [CrossRef]

14. Viswanadham, B.V.S.; Phanikumar, B.R.; Mukherjee Rahul, V. Swelling behaviour of a geofiber-reinforced expansive soil. Geotext. Geomembr. 2009, 27, 73-76. [CrossRef]

15. Sivakumar Babu, G.L.; Vasudevan, A.K.; Sayida, M.K. Use of Coir Fibers for Improving theEngineering Properties of Expansive Soils. J. Nat. Fibers 2008, 5, 61-75. [CrossRef]

16. Ramana Murty, V.; Praveen, G.V. Use of Chemically Stabilized Soil as Cushion Material below Light Weight Structures Founded on Expansive Soils. J. Mater. Civ. Eng. 2008, 20, 392-400. [CrossRef]

17. Yazdandoust, F.; Shahaboddin Yasrobi, S. Effect of cyclic wetting and drying on swelling behavior of polymer-stabilized expansive clays. Appl. Clay Sci. 2010, 50, 461-468. [CrossRef]

18. Miao, H.H. Chemical Modify of Expansive Soil. Master's Thesis, Dalian University of Technology, Dalian, China, 2007. (In Chinese)

19. Al-Rawas, A.A.; Hago, A.W.; Al-Sarmi, H. Effect of lime, cement and Sarooj (artificial pozzolan) on the swelling potential of an expansive soil from Oman. Build. Environ. 2005, 40, 681-687. [CrossRef]

20. Al-Mukhtar, M.; Lasledj, A.; Alcover, J.F. Behaviour and mineralogy changes in lime-treated expansive soil at $20^{\circ}$ C. Appl. Clay Sci. 2010, 50, 191-198. [CrossRef]

21. Al-Mukhtar, M.; Lasledj, A.; Alcover, J.F. Behaviour and mineralogy changes in lime-treated expansive soil at $50{ }^{\circ}$ C. Appl. Clay Sci. 2010, 50, 199-203. [CrossRef] 
22. Sharma, R.K.; Hymavathi, J. Effect of fly ash, construction demolition waste and lime on geotechnical characteristics of a clayey soil: A comparative study. Environ. Earth Sci. 2016, 75, 1-11. [CrossRef]

23. Alrubaye, A.J.; Hasan, M.; Fattah, M.Y. Improving geotechnical characteristics of Kaolin Soil using silica fume and lime. Spec. Top. Rev. Porous Media 2016, 7, 77-85. [CrossRef]

24. Federico, A.; Vitone, C.; Murianni, A. On the mechanical behaviour of dredged submarine clayey sediments stabilized with lime or cement. Can. Geotech. J. 2015, 52, 2030-2040. [CrossRef]

25. Sadeeq, J.A.; Ochepo, J.; Salahudeen, A.B.; Tijjani, S.T. Effect of bagasse ash on lime stabilized lateritic soil. Jordan J. Civ. Eng. 2015, 9, 203-213.

26. Kalkan, E.; Akbulut, S. The positive effects of silica fume on the permeability, swelling pressure and compressive strength of natural clay liners. Eng. Geol. 2004, 73, 145-156. [CrossRef]

27. Nalbantoğlu, Z. Effectiveness of Class C fly ash as an expansive soil stabilizer. Constr. Build. Mater. 2004, 18, 377-381. [CrossRef]

28. Ene, E.; Okagbue, C. Some basic geotechnical properties of expansive soil modified using pyroclastic dust. Eng. Geol. 2009, 107, 61-65. [CrossRef]

29. Hossain, K.M.A.; Mol, L. Some engineering properties of stabilized clayey soils incorporating natural pozzolans and industrial wastes. Constr. Build. Mater. 2011, 25, 3495-3501. [CrossRef]

30. Harichane, K.; Ghrici, M.; Missoum, H. Influence of natural pozzolana and lime additives on the temporal variation of soil compaction and shear strength. Front. Earth Sci. 2011, 5, 162-169. [CrossRef]

31. Hossain, K.M.A.; Lachemi, M. Stabilized building blocks incorporating volcanic ash and finely ground natural lime. In Proceedings of the 1st Canadian Conference on Effective Design of Structures, McMaster University, Hamilton, ON, Canada, 10-13 July 2005.

32. Harichane, K.; Ghrici, M.; Kenai, S. Effect of the combination of lime and natural pozzolana on the compaction and strength of soft clayey soils: A preliminary study. Environ. Earth Sci. 2012, 66, 2197-2205. [CrossRef]

33. Deocampo, D.M.; Behrensmeyer, A.K.; Potts, R. Ultrafine clay minerals of the Pleistocene olorgesailie formation, southern Kenya rift: Diagenesis and paleoenvironments of early hominins. Clays Clay Miner. 2010, 58, 294-310. [CrossRef]

34. National Energy Administration. Analysis Method for Clay Minerals and Ordinary Non-Clay Minerals in Sedimentary Rocks by X-ray Diffraction (SY/T 5163-2010); Petroleum Industry Press: Beijing, China, 2010. (In Chinese)

35. Ministry of Transport of the People's Republic of China. Test Methods of Soils for Highway Engineering (JTG E40-2007); China Communications Press: Beijing, China, 2015. (In Chinese)

36. Ministry of Transport of the People's Republic of China. Test Methods of Materials Stabilized with Inorganic Binders for Highway Engineering (JTG E51-2009); China Communications Press: Beijing, China, 2009. (In Chinese)

37. Ministry of Transport of the People's Republic of China. Specification for Design of Highway Subgrades (JTG D30-2015); China Communications Press: Beijing, China, 2015. (In Chinese)

38. Gadouri, H.; Harichane, K.; Ghrici, M. Assessment of sulphates effect on $\mathrm{pH}$ and pozzolanic reactions of soil-lime-natural pozzolana mixtures. Int. J. Pavement Eng. 2017. [CrossRef]

39. Harichane, K.; Ghrici, M.; Kenai, S.; Grine, K. Use of Natural Pozzolana and Lime for Stabilization of Cohesive Soils. Geotech. Geol. Eng. 2011, 29, 759-769. [CrossRef]

40. Keller, W. Classification of kaolins exemplified by their textures in scan electron micrographs. Clays Clay Miner. 1978, 26, 1-20. [CrossRef]

(C) 2018 by the authors. Licensee MDPI, Basel, Switzerland. This article is an open access article distributed under the terms and conditions of the Creative Commons Attribution (CC BY) license (http:// creativecommons.org/licenses/by/4.0/). 